論 文

\title{
農牧林家と企業の連携による砂棘栽培に関する一考察 一内蒙古自治区和林格爾県の事例を中心として一
}

\author{
姚 \\ 制 $^{1}$ ・ 小 池 正 雄 ${ }^{2 * *}$. 李 阿拉木斯 ${ }^{1}$
}

\begin{abstract}
姚粀・小池正雄・李 阿拉木斯：農牧林家と企業の連携による砂棘栽培に関する一考察一内蒙古自治区和林格 爾県の事例を中心として一, 森林計画誌 $41: 73 \sim 84,2007$ 本研究は, 経済がたち遅れている中国の西北 地域において，政府が森林造成と利用（林産業の発展）を目的に採用した企業参入政策の導入後における各農 牧林家の栽培の現状を把握し，現在の課題を明らかにすることを目的としている。本論文によって次の 2 点が 明らかになった。(1)調査地域の個別農牧林家による砂棘栽培には，企業と連携していない旧品種栽培夕イプ と, 企業と連携している新品種栽培タイプの 2 形態が存在する。それら 2 形態において栽培された砂棘の利用 方法は共に，果実の販売及び落ち葉を燃料として利用することとなっている。しかし，旧品種栽培夕イプには 様々な問題点が存在する。旧品種の砂棘林は分散しており, 砂棘には棘が多く, 採取条件が劣悪で, さらに果 実の販路が確立されていないなどの悪条件下での経営を行っている。その上，砂棘栽培といっても撫育・管理 作業は一切行っていないことから, 今後, 砂棘林の枯死, そしてそれを栽培する農牧林家の収入減少に伴い生 活にも支障が発生すると予測される。一方，企業に提供を受けている新品種の砂棘を契約栽培している農牧林 家は管理が行き届いており，安定的な収入を得ている。(2) 2 形態の農牧林家の砂棘栽培は共に，農牧林家の家 計収入の大きなプラスとなっているが，両者において，収入の格差が生まれている。その原因は，企業と連携 するためには資本金と労働力が必要であるが，それに対応できる農牧林家と対応できない農牧林家に二極化し たことによっている。今後は, 政府が農牧林家間に扔ける収入格差を縮小するため, 先ず全ての農牧林家が企 業と連携することができる枠組み構築が必要であろう。次に投下資金を持たない農牧林家に対しては，成林段 階に至るまでの育成段階においても収入を得られるよう，補助金の交付の枠組みの構築が必要であろう。最後 に砂棘栽培における労㗢生産性を上げるべく全作業過程における機械化を促進させる必要がある。
\end{abstract}

Tong YAO, Masao KoIKE and Alamusu LI : A Study on the Joint Cultivation of Hippophae rhamnoides L. by Noubokurinka (farming households dependent on grazing and forestry) and Private Enterprise: A Case Study of Helinger County in Inner Mongolia, J. Jpn. For. Plann. 41: 73 84, 2007 This paper focuses on the case study example of a county in the poor northwestern region of China. The local government recently introduced a policy of joint venture participation in forest construction and utilization (the development of forestry industry). This paper aims to grasp the current state of Hippophae rhamnoides L. cultivated by noubokurinka (farming households dependent on grazing and forestry) and identify the current issues involved. The two main conclusions of this paper are. (1) There are two types of Hippophae rhamnoides L cultivated by noubokurinka. In the previously used type the noubokurinka didn't cooperate with local enterprises which they now do. In both cases, the noubokurinka sell off the fruits of the Hippophae rhamnoides L. and use its leaves as fuel. However, compared with the new type, the previous type of cultivation resulted in less income and caused various problems. One reason is that the noubokurinka were using an old variety of Hippophae rhamnoides L. This variety had more spines, its forests were dispersed over a large area and the condition of picking fruits was bad. Also the

*連絡・別刷請求先 (Corresponding author) E-mail : makoike@gipms.shinshu-u.ac.jp

1 信州大学大学院総合工学研究科 Interdisciplinary Graduate School of Science and Technology Shinshu University, 3-1-1 Asahi, Matsumoto City, Nagano 390-8621.

2 信州大学農学部 Faculty of Agriculture Shinshu University, Minami-minowa, Nagano 399-4598. 
market for this fruit was not well established. Furthermore the fact that pruning and maintenance is not taking place would suggest the likelihood of the death of these plants and the accompanying repercussions on the lifestyle of the noubokurinka caused by the reduced income. Conversely, the noubokurinka who are contracted to cultivate the new varieties of Hippophae rhamnoides L. offered by the enterprises are achieving management goals and have a stable income. (2) The second type of cultivation has increased the household income of noubokurinka, but an income discrepancy has emerged on both sides. The reason is that there is a need for capital and labour force in order to make a joint venture with private enterprise and this has caused a subsequent polarization of the 'haves' and 'havenots' among the ranks of the noubokurinka. In order to decrease the income discrepancy between different noubokurinka, the government should build a joint venture so that all noubokurinka can work in tandem with private enterprise. Next it should create a mechanism for the distribution of aid money to help noubokurinka who have insufficient funds to ensure they get enough income to raise their own forest. Lastly, mechanization should be promoted across the board to improve labour productivity in the cultivation of Hippophae rhamnoides.

\section{I はじめに}

中国政府による「社会主義的市場経済」政策の推進 と共に森林からの木材収穫が激増し，森林の果たす多 面的諸機能が発現しにくくなったので，森林法は1998 年にその機能を重視する方向性を持った新森林法へと 改正された。その一環としての植林事業に㧈いては, 植林の主体である農民の植林への意欲を高揚させるた め, 自然環境に配慮すると同時に森林利用の助成・促 進，すなわち林産業の発展を促す政策が採用されてい る(4)。

しかし請負制の下での非公有制林業 ${ }^{* 1}$ 生産は 1 戸・ 1 世带の単位で行われて扔り，組織化されていな いため，販路は狭く，また販売市場が未確立であるこ とと出荷が組織化されていないことから販売金額は低 迷し，農民の所得は低い水準となっている。特に西北 地域においては, インフラ整供が未発達で, 自然条件 や，樹木の生育条件が悪いことから，森林資源が成熟 して㧍らず利用可能な森林資源が少ないため，林产業 は発展の初期段階にとどまり続けている(3)。

国務院は1996年の「九五星火計画発展要綱」(7)及び, 改革開放後における「三農問題」*2の解決に関する重 要な政府の指令文書である2003年の「一号文件」の中 で，筆頭（龍頭）企業*3(以下は企業とする) の参入 は林産業の活性化を促進させ，農民を貧困から脱却さ せる重要な手段であると明確に指摘している(14)。

ここでは，これまでの砂漠植林に㧍ける企業の参入 に関する研究をフォローし, 本研究の位置づけを明ら かにすることとしょう。

この分野に関する研究は, 政府によって林産業の発 展に打ける企業参入政策が提言された1996年頃から始 まった。朱は中国の砂漠植林の現状や現存する問題点 に関する分析を通じて, 林産業の発展の初期段階に㧈 ける企業参入の重要性について述べている。その中で
企業の参入は，分散する農家を集中させ，生産物の商 品化を加速させることに慗がると指摘している(10)。 周は非公有制経済の割合が大きな位置を占めている中 国農村の特殊性を踏まえた上で, 企業が林産業の発展 に参入する段階に扔いて採用すべき政策・制度の面か ら提言を行っている(11)。しかしこれらはいずれも理 論面の研究であり, 実態調查を踏まえての研究成果で はない。

唐は，竹生産に㧍いて竹を資源から商品へ転換する 過程に扔汀る企業と農牧林家の合作方式を実態調查に 基づいて明らかにしており，具体的に企業参入政策を 取り上げてはいるが, 植林の主体である農家側の対応 についてまでの問題意識に基づいての研究にまでは至 っていない(12)。

そこで本研究では, 砂棘栽培を対象として, 砂棘利 用の先進地である内蒙古自治区和林格爾県 $* 4$ を事例 に取り，農牧林家が実施している砂棘栽培への企業参 入に対する農牧林家側の対応を見る中で, 砂棘の生 産・利用の現状と課題を明らかにする。中国に打いて 砂棘は世界の全栽培面積の $90 \%$ 以上に及ぶ 200 万 ha の 面積で栽培されており, 砂漠植林にとって重要な植物 であるばかりではなく, その加工生産物は医薬品, 食 品などまで広い分野に及んで活用されている(13)。

\section{II 調查地の概況と砂棘}

\section{1. 調査地の概況}

本研究の調查地は, 内蒙古自治区和林格爾県大紅城 郷 D 村である。和林格爾県は，内蒙古自治区の中央 にあり，区都呼和浩特市まで $35 \mathrm{~km}$ ，黄河の中流地域に 位置している (図- 1 )。年間平均気温は $5.6^{\circ} \mathrm{C}$, 年間 降水量は $391.6 \mathrm{~mm}$, 年間蒸発量は $2,340 \mathrm{~mm}$ となっており, 蒸発量が降水量の約 6 倍に達する乾燥地域に属する。

基幹産業は農業, 牧畜業, 林業であるが調査地にお 
いては長期にわたる不適切な土地利用により，土壌流 失し，耕地の砂漠・風食化した砂が風砂となり，移動 している。従って, 耕作を行っても, 風砂が耕地に堆 積してしまう。このような厳しい自然条件の中，和林 格爾県は，第一次産業が未発達であることから1997年 までは呼和浩特市において，9つの旗，県，区の中で 最も貧困である県とされていた。そのため, この地域 は呼和浩特市の脱貧モデル地域と位置づけられ，貧困 対策の象徵的な存在になっている地域である。

こうした状況の下，自然環境の改善を目的とする植 林事業と, 地域住民の生活を支える農牧畜業とどのよ うに共存させていくかがこの地域の最も重要な課題と なっていた (15)。

そこで和林格爾県政府は市場経済の発展につながる 政策を取り入れ，様々な分野で企業の参入政策を採用 した。この企業との連携により, 地域経済を振興させ ることに成功し，2002年における財政収入は1997の8 倍，農牧林家の純収入は1997年の1.62倍にまで増加し た。緑化を進めた結果2004年には「全国緑化模範県」 として表彰され，また和林格爾県は企業の参入を通じ て農村経済を発展させる模範であるとされるにまでに 至っている(5)。

$\mathrm{D}$ 村は217戸，1,128人からなる集落である。総土地 面積は25,215畧*5, そのうち, 農地は3,384畧, 林地
は 8,070 欯，人口 1 人当りの平均耕地面積は 3 畧であ る(2)。

我々は現地における実態調査を，2006年の8月から 9 月にかけて実施した。和林格爾県の林業局，D村 の行政担当者への聞き取り調査をした上で，村長から の聞取り調査を実施した。その結果に基づいて2006年 現在，砂棘栽培を活発に行い，一定の収入を維持して いる農牧林家のうち，企業と連携している農牧林家20 戸と連携していない農牧林家10戸，合計30戸の農牧林 家への個別聞取り調查を実施した。

\section{2. 砂棘について}

ここで, 砂棘の特徵・栽培方法と用途に関して述べ ておこう。

（1）特徴 砂棘 (Hippophae rhamnoides L.) はグミ科 サキョク属に属している。樹高は 1 ～ $5 \mathrm{~m}$ (品種に よっては $10 \mathrm{~m})$, 耐乾・耐寒・耐砂性などに優れた 中国全域に分布する落葉樹である。葉は線形一線状 披針形で，特有の鱗片状の毛が葉や枝にある(16)。 また砂棘という名前の通り，枝には鋭く硬い棘があ る。砂棘の実の果汁にはカルシウム, 鉄, カリウム, 覀鉛など，さまざまなミネラル，さらにはビタミン $\mathrm{B}, \mathrm{C}, \mathrm{E}, \mathrm{F}, \mathrm{K}$, カロテン, 必須アミノ酸を含 むアミノ酸各種が豊富に含まれている(8)。

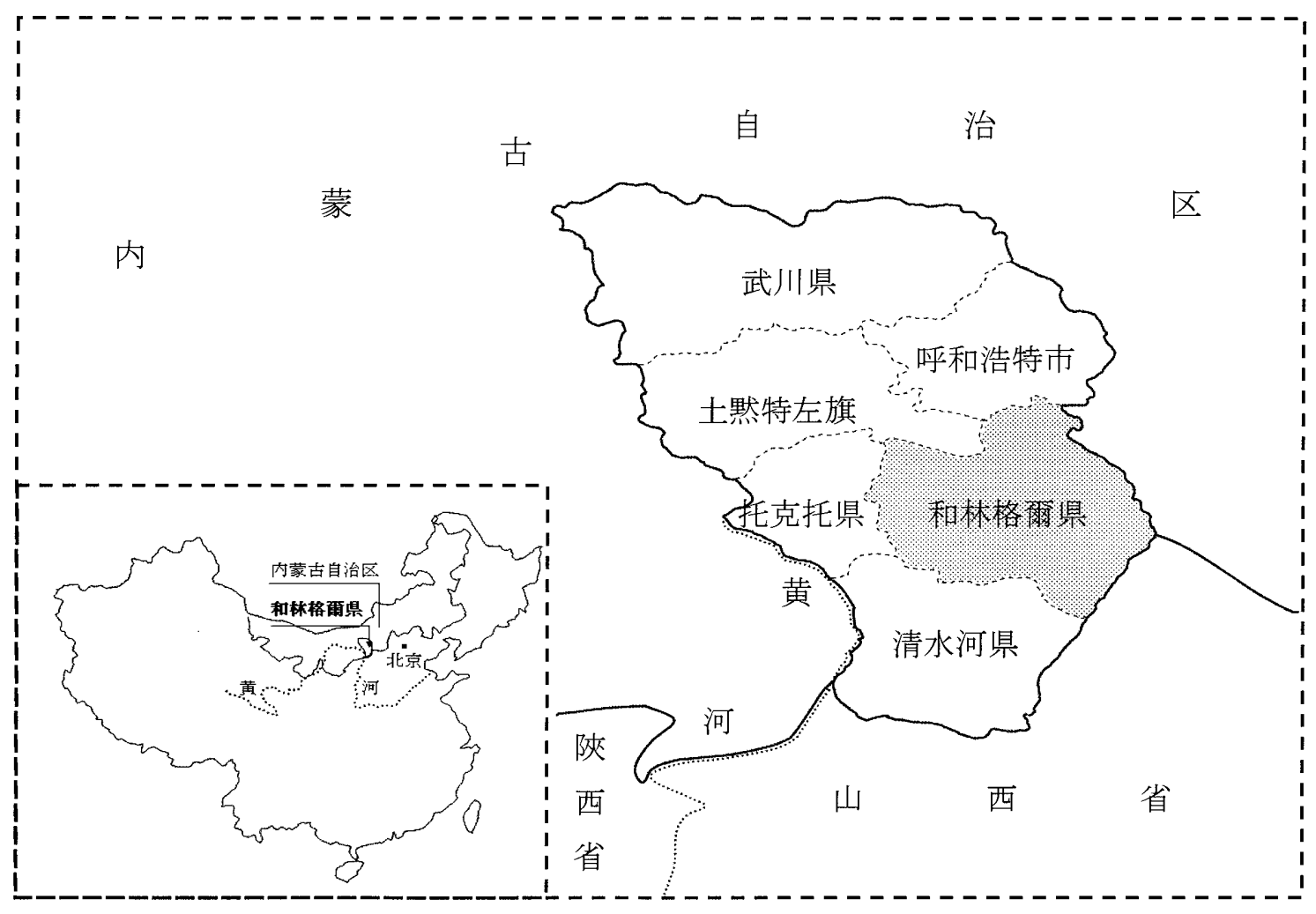

図一 1 調査地の位置 
（2）栽培 栽培用苗木は $1 \sim 2$ 年生, 高さは 0.4 ～ $1 \mathrm{~m}$ のものを用いる。栽培方法は, まず直径 $40 \mathrm{~cm}$, 深さ $35 \mathrm{~cm}$ の植え穴に苗木を入れる。覆土する際には，表 土を根に近づかせ，土が穴の 3 分の 2 まで入った時 に，苗木をすこし上に持ち上げ，根を土塞に十分接 触させるように広げる。つぎに穴に完全に覆土をし， 足でしっかりと踏み固める。最後に土壤の水分を保 持するために穴の表面に薄く土を盛り，水を撒く。 斜面では土砂流失と侵食防止のために，また斜面を 利用して雨水を集めるために，など等高線状に配置 する必要がある。

栽培密度は良好的な生育のためには基本的に 1 畧 当り 220 株， 1 株の株間は $1.5 \mathrm{~m} \times 2 \mathrm{~m}$ か $2 \mathrm{~m} \times 3 \mathrm{~m}$ が適当であるが，販売用に果実の採取作業を考虑す る場合には $2 \mathrm{~m} \times 4 \mathrm{~m}$ の間隔が必要である。

砂棘は適宜（6〜8年に 1 回）に刘取りさえすれ ば切り株から萌芽し, 成長を続ける。但し刚取る際 に, 可能な限り切口の位置を地祭近くにし, 切口面 のひび割れを避け，滑らかに切断しなければ萌芽し ない場合がある。また砂棘の枝を常に一定の高さに 保つ剪定作業が重要である。それは果実を採取しや すくし，枝の成長に必要な栄養分を果実に与え，収 穫量を確保するためである。しかしそれらの作業は 現段階においてはすべて手作業によるものである。

（3）用途 砂棘は根が水平に伸び発達した根系を形成 し，さらにその根から新しい個体が地上に出る（根 萌芽) 能力があるため砂漠緑化の先駆植物として用 いられている $(6)$ 。斜度10３5度の土地では，4年 生以上の砂棘林は根系がさらに発達するため土砂流 失防止機能が高く，被覆率が $40 \%$ 以上に達した場合 は，砂丘の固定が可能となる。また枝は刈り込みに も強く, 収穫後新しい枝葉が芽吹き, 容易に枝葉が 繁るため薪や飼料としても利用できる。そして枝の 硬い刺の存在により，家畜の侵入を防ぐため有効な 生垣となる。根には根粒菌が付き, 空中窒素の固定 をし，土壤を肥やすことができる。さらに沙棘の果 実には栄養分が豊富なことから現在中国では加工品 として化粧品, 健康食品と養毛剂に使われている。 近年日本でもプロゲステロン*6 健康食品として注 目され始めている (9)。

\section{III 調査農牧林家の概況}

まず，調査農牧林家の概況について示す（表－1， 表-2)。

農牧林家の主たる収入源は農業・牧畜業・林業・賃 労働である。主な商品農作物は, トウモロコシ, ダイ ズ, 綿羊 (羊毛, 肉), 牛 (牛乳), 砂棘の果実となっ
ている。賃労働の就労先として, 男性は呼和浩特市の レンガ製造所で，技能労働者または単純労働者として の就労であり，女性は飲食業における就労の場合が多 w。

D 村では1982年からの国による「植樹造林」政策に 従い，砂棘による栽培事業を開始した。その後1984年 に村の管轄下にある砂棘林を農民に無償で分割し た*7。この林地を正常に管理することができた農牧 林家は，この時分割された林地を現在も経営している が，その中においては，砂棘生産での収入が低いため 分割林を放置した農牧林家も多く存在していた。この ように放置された土地は村に返還しなければならず， それらの土地について村は新たに分割を行い, 再配分 された土地を得た一部の農牧林家の砂棘林面積は拡大 した。立地条件に規定され砂棘の生育状況の悪い分割 されることのなかった砂棘林に対して，村ができる範 囲で管理していたが，労働力が不足していたために大 面積の砂棘林での枯死を招いてしまい，結果的に多く の土地が再び荒廃地に戻ってしまった。

こうした状況下において，D村では1999年に企業 参入政策を採用した。その年に村は新たに返還された 一部の砂棘林についてあらためて請負農牧林家を募集 した。村が請負わせる土地の多くは荒廃した土地では あったが参入する企業が無償で新品種の苗木を提供 し, 運輸, 販売など今までの問題点が多く存在してい た一連の流れをすべてクリアーできる条件が整備され たため, 荒廃地を請負う農牧林家が出現したのである。

企業参入後, $\mathrm{D}$ 村における砂棘の栽培は 2 つの存 在形態に分かれるようになった。1つのタイプは企業 と連携しておらず，村に配分された旧品種の砂棘栽培 を行う形態である。もう１つのタイプは企業と連携し ており, 企業が提供する新品種の砂棘栽培を行う形態 である。

ここでは先ず旧品種と新品種についての説明をして おこう。旧品種の砂棘は, 1980年代以降共同で栽培し ているものである。表一 3 に示すように，旧品種の樹 冠直径は $1 \mathrm{~m}$ ，樹高は $1.8 \mathrm{~m}$, 棘は $10 \mathrm{~mm}$ 四方に $8 \sim 10$ 個が付き，果汁率は60〜70\%，1 畧から実の収穫量は 約 $200 \mathrm{~kg}$ である。新品種は企業がモンゴル人民共和国 から持ち达み，農牧林家に提供したものである。旧品 種に対して新品種は以下の 3 点の優位性を持ってい る。1）樹高が高く, 樹冠が大きいため, 旧品種に比 べ2 倍の防風效果がある。2）棘が少なく, 普通の品 種の $2 \%$ 未満の棘があるだけであるために採取しやす い。3）実の収穫量が多く旧品種の1.75倍に達してお り, 果汁率も10\%高い。

それでは以下において, 旧品種の砂棘栽培農牧林家 と新品種の砂棘栽培農牧林家の経営の状況を具体的に 


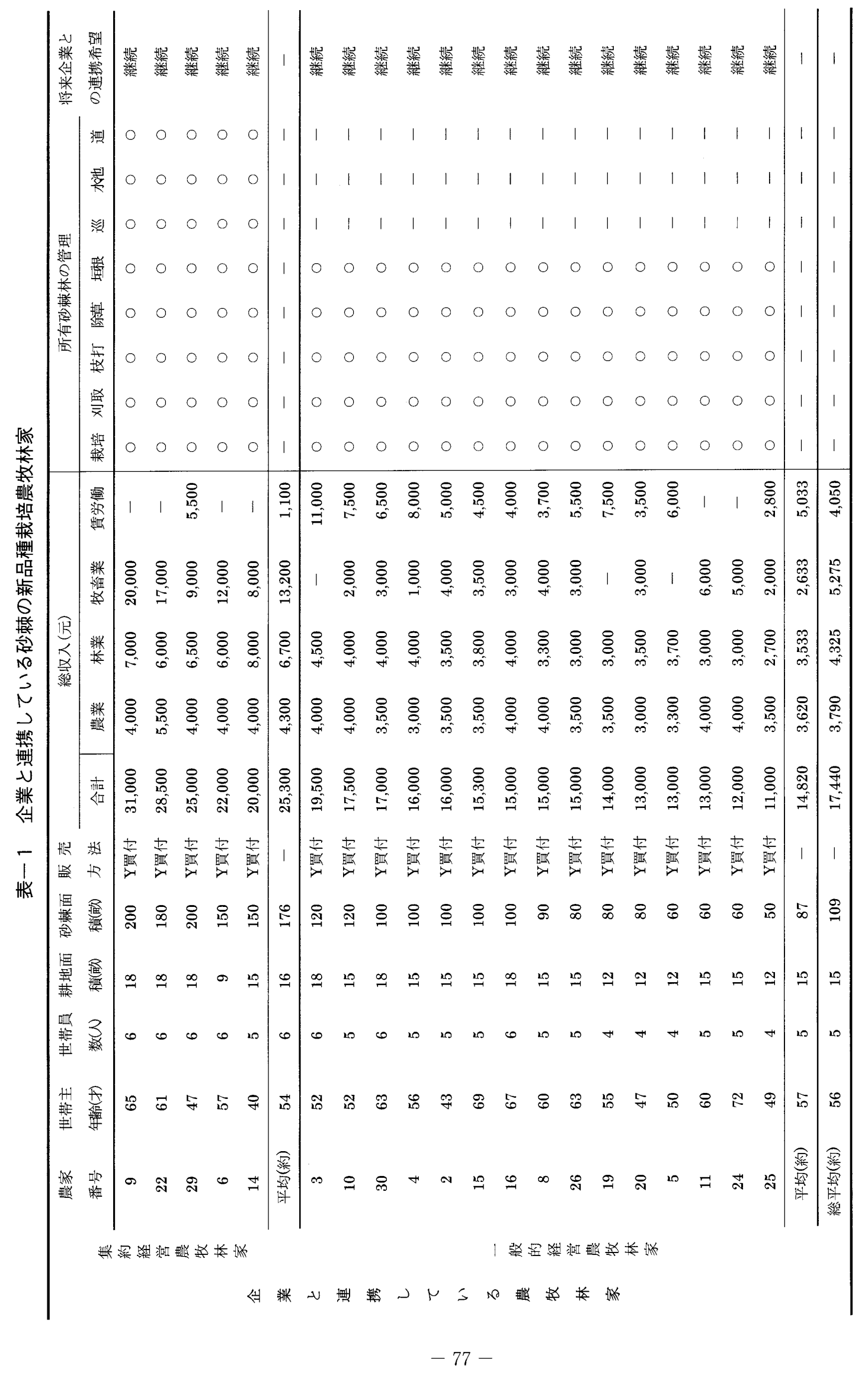




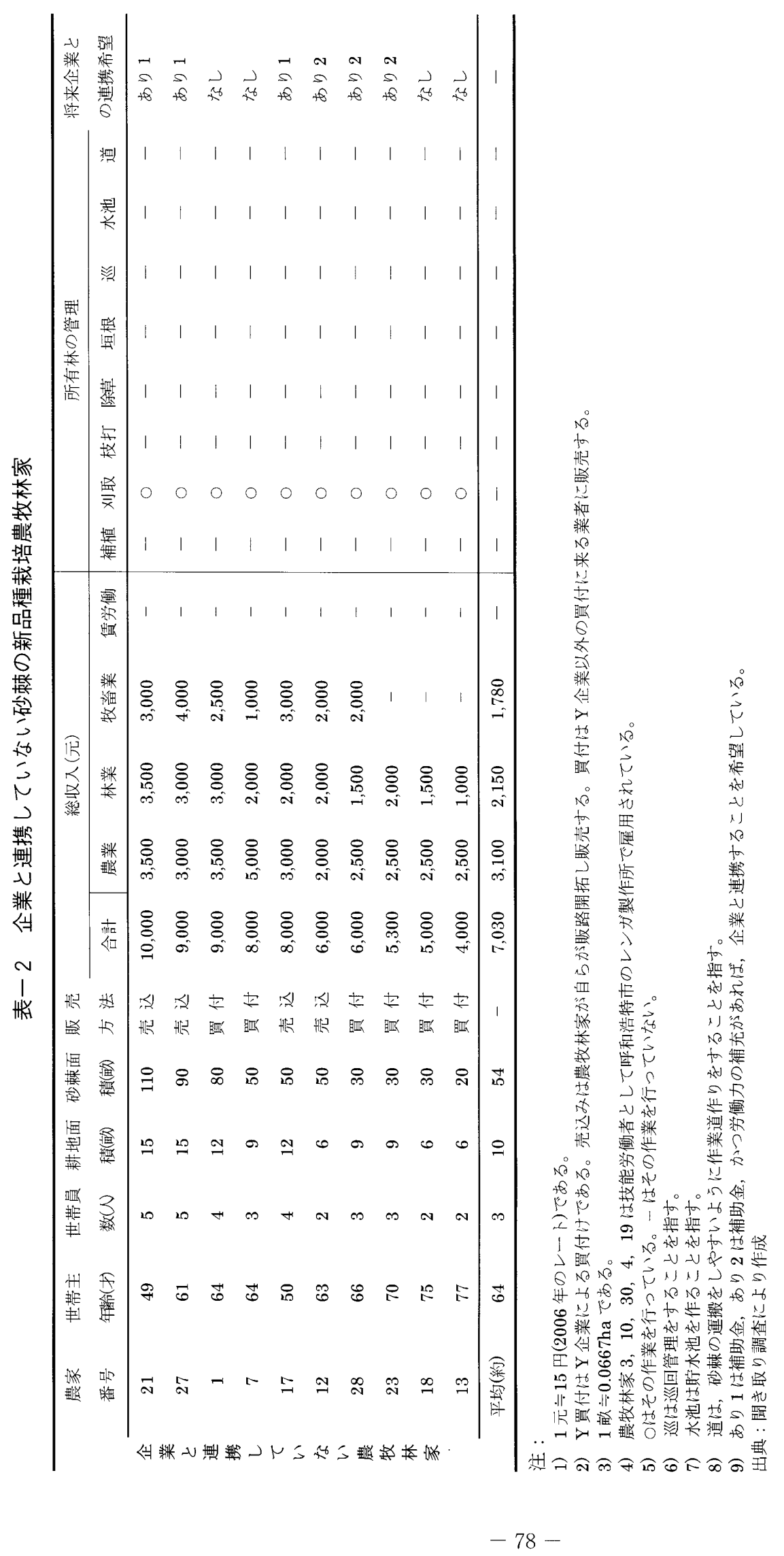


みていくこととしよう。

\section{表一 3 旧品種と新品種の比較}

\begin{tabular}{llcc}
\hline & \multicolumn{1}{c}{ 項目 } & 旧品種 & 新品種 \\
\hline 樹冠直径 & $(\mathrm{m})$ & 1.0 & 1.5 \\
\hline 樹高 & $(\mathrm{m})$ & 1.8 & 2.2 \\
\hline 棘の状況 & $($ 個 $/ 10 \mathrm{~mm})$ & $8 \sim 10$ & 0.15 \\
\hline 新鮮果実の重さ $(\mathrm{g} / 100$ 粒 $)$ & 53.6 & 86.8 \\
\hline 果汁率 & $(\%)$ & $60 \sim 70$ & $70 \sim 80$ \\
\hline 果実の収穫量 & $(\mathrm{kg} /$ 畧 $)$ & 200 & 350 \\
\hline
\end{tabular}

出典：Y 企業の内部資料及び聞き取り調查により作成

\section{N 企業と連携していない砂棘の 旧品種栽培農牧林家}

(1) 経営する砂棘林地について

企業と連携していない農牧林家は，1980年代後半か ら砂棘栽培を経営の一部に取り込んだ。経営する砂棘 林地面積は平均54畧である。経営する林地の分割にお いては, 土地により収穫量が偏ってしまうことがあり， 村は砂棘林地の収穫量を各農牧林家間で平均的にする ため, 共同で栽培した砂棘林の立地条件と砂棘の生育 状況（本数）に応じて各農牧林家に請負わせる分割方 式を採用した。但し農牧林家は経営する砂棘林地に対 して，地上権はあるが，土地については使用権のみで ある。上述の分割方式の採用により，1 回目の分割時 に 1 農牧林家当り 2 筒所以上の砂棘林を経営する場合 が多くなっていたが，2回目の分割でさらに3 䇢所以 上の砂棘林を経営する農牧林家も存在するに至ってい る。すなわち, 各農牧林家が経営する砂棘林は幾つか の団地に分散している場合がほとんどである。

（2）経営する砂棘林の利用と管理状況

現段階に扔いて農牧林家が栽培している砂棘林の利 用と管理の実態を見てみよう。農牧林家は砂棘の果実 の販売をして抢り，また自家用の燃料として落ち葉を 採取・利用している。土地の利用権を付与されている ことへの見返りとして, 村側は農牧林家に砂棘林への 水やり, 施肥, 除草, 補植, 刏取りなどの管理作業を 義務付けている。しかしそれらは自家労働力のみで行 なわざるを得なくなっており，また資金が不足してい るため雇用労働力の利用は不可能であり, 管理作業の 全てを自家労働力のみで行うことは困難な状況となっ ている。現段階において, 農牧林家は砂棘の枯死防止 に不可欠な刈取り作業として $6 \sim 8$ 年に 1 回砂棘を計 画的に 1 列ごとに地際から刚取る作業を行っている が，その他の保育作業はほとんど行うことができてい ない。

（3）経営する砂棘林からの収穫物の販売及び収入の状況 販売までの作業は以下の通りである。農牧林家は各
自の収穫物を村に設けられた集荷場に集め，砂棘の果 実は，実が付いた枝 1 本単位で販売する。実が付着し ている枝の 1 本当りの重量は総重量の10 1 $15 \%$ とする ように砂棘販売市場で定められている。農牧林家は各 自集荷場で枝付きの実の選定作業を行う。そして，計 量しトラックへと積み込む。販売には 2 つ方法が存 在している。その 1 つは農牧林家自らが業者に売り达 む方法である。業者は実の買取りを望んでいるが，枝 から実を分離させるのは難しいため農牧林家の販売す る実にはほとんどの場合に枝がついている。しかし自 家用の 3 輪車または 4 輪車で業者まで輸送するに際し て，大量に詰め込むと実が潰れてしまうので，積載 量を少なくしなければならず，輸送コストが非常に高 くなるという問題点が存在している。もう１つは買付 業者に販売するという方法である。この場合に少額の 運賃で販売が可能であるが, 買い手市場の商品であり, 買付業者が現れない場合は，無収入となってしまうと いう問題点も存在している。また双方の場合共に，販 売価格の決定に関してはその都度交渉を行う場合が多 w。

2006 年の砂棘林からの平均収入は栽培農牧林家 1 戸 当り 2,150 元*8であった。各部門の平均収入を平均総 収入に占副割合から見ると,農業は $44 \%$,牧畜業 $25 \%$ を占めるのに対して，砂棘は $31 \%$ にまで達している。 その収入は出稼ぎに行けず，砂棘栽培に労働を投下す る世帯員が存在している農牧林家にとっては, 貴重な 副収入部門となっているといえよう。

その典型例としては農牧林家21があげられる。

農牧林家21は, 夫49歳と妻50歳, 世带主の両親 (71, 68 歳)，息子 25 歳の 5 人家族で構成されている。本格 的に砂棘の経営を始めたのは1991年であった。1990年 の段階では, 30站の砂棘林を保有するのみであったが, 1993年に村から砂棘林の再分割を受け，20䇉が増え， 1996年には 3 戸の農牧林家から60站を譲り受け，現在 まで段階的に110略まで搪大し， 3 䇢所の砂棘林団地 に分けて経営を行っている。このように段階的に砂棘 林の面積を拡大して規模拡大した事例は企業と連携し ていない他の農牧林家に扔いても見られる。

砂棘の果実の成熟時期は 8 月下旬～9月であり，採 取・収穫は11月から翌年の 2 月の間に家族全員で行 う。枝には棘が付いており危険だが，1株１株の間隔 が狭いため，保護用の手袋などを着用すると実が落ち てしまうことから，採取は女性が素手で行う熟練労働 によっている。な㧍，連年の収檴を確保するため，採 取は基本的に 2 年生の砂棘だけに限っている。3 籄所 のそれぞれの砂棘林で採取を行い，道まで運び，相包 し，自家まで運ぶという全作業は世带主夫婦と息子に よって行われている。燃料として利用する砂棘の落ち 
葉の収集は，基本的に世帯主の両親が行っている。落 ち葉採取の時期は，世帯主夫婦は綿羊の搾乳，羊毛の 刈込み，息子は販売などの作業に携わっている。この ように経営の各部門に家族労働を配分しており，この 農牧林家は所謂家族労作経営を行っているのである。 砂棘の果実の販売は前述のように枝がついたままであ ると運賃が装んでしまうため，農牧林家21の場合には 凍らせた実が付着している枝を地面に落とす作業をす る。これにより，枝と実を切り離し，実だけの輸送及 び販売を可能とした。しかし，それは大変な重労働で ある。

村から砂棘林の経営を請負った後において, 砂棘の 補植を行っていないため, 1 撂の砂棘の株数は20〜50 株と開きがあり，年間における販売量は5,000〜 $6,500 \mathrm{~kg}$ で，収入は $3,000 \sim 4,000$ 元と不安定である。 年間における落ち葉収集量は $3,000 \mathrm{~kg}$ であり，落ち葉 は燃料として利用されており，それによって，1年間 の石炭の購入費用の約半分は節約することができてい る*9。また石炭から落ち葉利用へというバイオマス 利用への転換は環境にも優しいといえる。砂棘からの 収入は決して多いとはいえないが，出稼ぎができない 状況下にあっては生活の大きな支えになっていると世 带主が聞き取りに対して回答していた。

一方, 砂棘の採取・収穫の際, 棘で怪我をしやすく, 手間と時間が必要とされる上，販路が不安定なことな どにより，得られる収入が少ないため撤退するものも 多く存在している。1996年までは旧品種の砂棘を経営 する農牧林家は30戸存在していたが，その内20戸の農 牧林家が相次いで離脱の意思決定をし, 村の許可を得 て現在まで経営を継続している10戸に砂棘林地を売却 した。

なぜ企業と連携をしなかったのかという我々の質問 に対して，農牧林家21，27，17は企業との連携も考元 ていたが，連携に必要な投下資金捻出の余裕がなく断 念したのだと回答した。資金を捻出することができな い理由として新品種は棘が少なくなり作業の効率が上 がったが，一方は棘が少ないために家畜に食べられた り，他人に盗まれたりしてしまうという新たな障害が 発生したことを指摘している。その結果, 家畜や人間 の無断侵入を防止するため新たに垣根を巡らすことが 必要とされ，それには挂金がかかるのみならず，巡視 管理も必要となってきているということであった。農 牧林家 $12 ， 28 ， 23$ は投下資金を所有しておらず，労働 可能な世帯員も少ないため連携をしなかったというこ とであった。

また農牧林家 1 は，1997年，1999年と2004年の 3 回 の旱䰠により, 砂棘の収穫量は全国的に少なく, 需要 が供給を上回ったため,いくつかの買付け業者の内で,
一番買付金額の高い業者に販売できた。よってそれら の年の収入が多かったため, 企業と連携しなくとも売 上げ収入が多くなる場合はあり，連携の必要性を認め ないと回答した。農牧林家 7 は企業に苗木を提供して もらっても，労働可能な家族員が少ないため，収穫量 や収入額が不確定であり，投資のリスクは大きいと判 断し連携をしなかったと回答した。農牧林家18と13で は, 高齢化が進み, 砂棘栽培に投下する労働力が存在 しないため企業と連携して，栽培経営を拡大するより も，現状維持を望んでいる。

\section{$\mathrm{V}$ 企業と連携している砂棘の 新品種栽培農牧林家}

\section{1. 参入企業の状況}

企業と連携している農牧林家の状況を説明する前 に，先ず企業参入の経緯を述べる。

$\mathrm{Y}$ 企業は1995年呼和浩特市に設立された。内蒙古自 治区の重点的なハイテク企業であると同時に, 経営の 多角化の一部門として砂棘加工販売部門にも進出し, 砂棘を含めた総合産業化, 研究開発を行い, 社員 2,000 人余りを抱える大型企業である。主たる製品は砂棘シ リーズの有機栄養食品, 効能性保健食品, 薬品, 化粧 品である。それに砂棘の優良品種の育成及び砂棘林造 成も実施している $(1)$ 。

$\mathrm{Y}$ 企業が連携による砂棘栽培を開始したきっかけは 以下の 2 点である。第 1 点目は1998年以後政府が経済 的に立ち遅れている地域の経済発展のためには企業十 農家という連携方式が重要な手段であるとしてこの方 式が採用され，推進されているという理由である。第 2 点目として, 企業側も砂棘の栽培を通じて, 生態系 の回復を中心とした自然環境の改善及び社会的経済発 展に寄与することを目的としていたという理由が挙げ られる。

1999年にY 企業とD 村は契約栽培を開始した。D 村は海抜が $1,800 \mathrm{~m}$ 以上あり, 天然資源の生態保護 区*10の中にある。砂棘の原料として企業が求めるも のは，農薬の残留物がない純粋な天然原料であるが, D 村の砂棘はこれを満たしているだけではなく, 立地 条件に規定されてビタミン, 鉱物質, 微量元素なども 豊富に含んでいる。このような理由から，Y 企業は 連携先としてこの地域を選定したのである。

その連携の基本は, 企業と農牧林家はリスクの共同 分担，利益の共有 ·協力に基づいてお互いが発展して いくという関係である。農牧林家と企業の契約に際し て, 双方の権利や義務及び利益については村委員会に より監督されることになっている。企業の責任によっ て農牧林家に不利益が発生した場合, 村民委員会が県 
政府に，県政府が内蒙古自治区政府に報告する。違約 であることが確認されれば，企業への貸付金を没収す ることとなる。反対に農牧林家が違約の場合, 請負地 を解約され，違約金を支払うことになる。

農牧林家が生産した生産物について，実を枝から分 離する設備（年間処理能力は 5 万トン）を導入し，実 を滤過し飲料を生産, また抽出装置で砂棘オイル（年 間抽出能力は 60 万トン) を生産している。その他新し い種類の薬剂生産ライン, 高精度 · 多機能の分析検査 器具及び優れた冷蔵冷凍生産装置などを所有してお り，砂棘の加工においては，世界で重要な位置を占め るにまで成長してきている(16)。1999年以降，Y 企 業の砂棘オイルはイタリア，香港，台湾向けにロット 輸出され，販路は確実なものとなってきている。これ からの会社としての方向性は，まずアジア市場での販 売実績を高め，つぎにヨーロッパ市場での販売規模を 広く開拓拡大し，アメリカ合衆国市場においては新し い取引先を開発する計画を立てている。

\section{2. 企業と連携している新品種栽培農牧林家}

(1) 経営する砂欶林地について

農牧林家が企業との契約栽培を開始したのは1999年 であった。経営砂棘林地の確保に関しては，農牧林家 が新規に植林を実施するという前提で村から荒廃地を 請負った。但し請負地は場所的に集中している場合が 多く，平均経営面積は109畧である。

(2) 経営する砂棘林の利用と管理状況

経営する砂棘林の経営の生産方向は企業と連携して いない農牧林家と同様に，砂棘の果実の販売及び燃料 とされている落ち葉の利用である。砂棘の契約栽培に おいて, 苗木は企業から提供され, 植栽, 除草・巡回・ 刈取りなどの管理，採取作業において技術の指導を受 けながら行っており，病虫害の予防・防除は企業に一 任している。このような栽培方式は農牧林家の権利と 利益の面で安定感を与え, 農牧林家の植林の積極性を 高めることができている。ちなみに契約は2005年まで は 1 年ごとに村民委員会の 2 名の構成員の立会いの下 で契約を行っていた。また長年にわたる信頼関係を築 き上げてきた結果として，2006年において，向こう20 年間の長期間にわたる契約締結を計画していると村長 が我々の聞き取りに回答した。

（3）経営する砂棘林の販売及び収入の状況

$\mathrm{Y}$ 企業と連携している農牧林家の生産物は，すべて 企業が買付けている。販売までの一連の作業は連携し ていない農牧林家と同様であるが販売に関して異なる 点は，販売価格の交涉をすることなく，契約通りの金 額を得られることである。砂棘林からの平均収入は 4,325元となっており，平均総収入に占める割合から

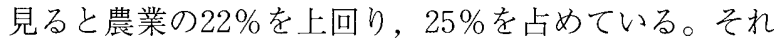
は比較的に総収入が多い農牧林家とっては更なるプラ スになっているといえよう。

企業と連携している農牧林家の砂棘栽培について詳 しくみると，砂棘林地の利用権利と管理義務は同様で あるが経営の集約度から見た場合集約経営農牧林家と 一般的経営農牧林家の 2 種類が存在していることが分 かる。

先ず集約経営農牧林家を考察しよう。

現在 D 村において，集約経営を行っている農牧林 家はわずか 5 戸（農牧林家 $9 ， 22 ， 29 ， 6 ， 14 ） に$ 過 ぎない。集約経営農牧林家の典型例として農牧林家 9 が挙げられる。

農牧林家 9 は夫 65 歳と妻 60 歳, 長男夫婦 (45歳， 46 歳), 次男 24 歳, 長女 21 歳の 6 人家族で構成されている。 企業と連携する前（1998年）までは，牧畗業を家業の 中心として営んできた。牧畜経営における飼育頭数の 増加と経営経験の積み重ね，また D 村は呼和浩特市 に近いことや親戚の計らいもあり，呼和浩特市にある 中国の乳業におけるシェアの上位を占める2つの乳業 資本, 畜産資本と生産物販売の契約を1996年に結んだ。 そのため自家で飼育している綿羊と乳牛のすべてはそ れらの会社向けに販売している。このようなことから， 農牧林家 9 は調査対象の中で最も裕福な農牧林家とな っている。

農業，牧畜業，砂棘の各部門への労働投下は家族全 員が分業しながら行っている。農業は主に世帯主夫婦 が行っており，長男夫婦，次男と長女が牧畜業を担当 する。家畜は主に羊肉，羊毛，牛乳の販売を目的とし て飼育されており, 男性は綿羊を屠殺し, 肉の販売, 飼料の貯蔵を担当し，女性は羊毛の刈り达みと牛の搾 乳を行う。

砂棘の栽培を開始したのは企業と連携を始めた1999 年であった。企業からの説明と技術指導を受けながら， 村から200畧の荒廃地を請負った。その年の3月に整 地を行い，4月の下旬に株の間隔を $1 \mathrm{~m} \times 1 \mathrm{~m}$ または $1.0 \times 1.5 \mathrm{~m}$ にし，砂棘栽培を開始した。そして 6 ～ 8 月に採取する際に作業しやすく，また収穫量を確保す るため，砂棘の枝を一定の高さに揃える枝の剪定作業 を行った。剪定作業はその後も毎年行っている。2000 年に家畜や人間の無断進入を防ぐために経営する砂棘 林地の周囲を木の坦根で囲み，その後少しずつ木から 有棘鉄線に変えた。有棘鉄線の垣根はセメント柱と有 䊂鉄線よりなる。高さ $3 \mathrm{~m}$ のセメント柱を $4 \mathrm{~m}$ 間隔で 1 本を設置し,有棘鉄線は $30 \mathrm{~cm}$ の間隔で 6 本, 高さ $2 \mathrm{~m}$ の範囲に張られている。

放牧可能な時期である10月から翌年の 3 月下旬の間 に巡回管理を行い*11，その合間に除草作業も実施し 
た。2003年に 5 戸の農牧林家が，旱魅による水不足を 解消するため共同出資によって節水小型ダム蓄水管理 のための灌溉用溜池を造成した。これにより，砂棘は 液果類であるため, 適量の給水と施肥によって実の水 分が保たれ，肥大し，収穫量を $35 \%$ ～55\%増加させる ことが可能となった。また 3 輪や 4 輪のトラクターの 進入ができない場所では関連する農牧林家が協力し合 い，トラクターが通過できるような作業道を作るなど の道路改良を実施したことで，収穫物の管理・運輸の 效率を上げることができた。表一 1 からも分かるよう に, 集約経営農牧林家は一般的経営農牧林家に比べ, 砂棘からの平均収入が約 1.9 倍にもなっている。現段 階ではこれまでの投下資金の回収にはまだ時間がかか るが，今までの砂棘からの収入実績からみると十分に 採算がとれ, 将来的にそれ以上の利益を生み出すこと

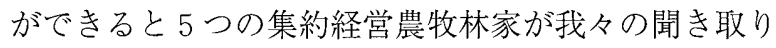
に回答した。

\section{（2）一般的経営農牧林家}

一般的経営農牧林家において，農業，牧畜業と砂棘 栽培は行われているが，家族労衝力の多くが賃労働に 投下されている。企業との連携による砂棘の栽培は 2001年以降行われている。集約経営農牧林家と同じく 企業と連携を開始してから, 企業の指導に従い, 整地, 栽培，剪定などの管理作業を行っているが，定期的な 巡回管理, 灌溉用溜池の造成, 作業道作りなどの経営 の集約度を上げた集約栽培は行われていない。砂棘の 栽培は農閑期や賃労働の休日を利用して行われ，余㮃 労働力の完全燃焼だと考えているが実際，ほとんどの 農牧林家は砂棘林からの収入よりも賃労働収入のほう が農牧林家総収入に占める割合が大きい。

賃労働を行う農牧林家の実例をみてみよう。農牧林 家 3 は2002年に企業との連携を開始したが, 世帯主 $(52$ 歳) と長男 (21歳) は 1 年のうち平均 $6 \sim 10$ ケ月間呼 和浩特市で出稼ぎ賃労働に就労している。農業や砂棘 の植林はほとんど世帯主の母親 (73歳), 妻 (50歳) が中心となって行い, 次男, 三男 (18歳, 16歳) は学 校が休みの時にのみにその仕事を手伝っている。また 在学中の子供に学費以外の雑費が毎月のように必要で あるため, 灌溉用溜池の造成などへの資金捻出は厳し い状沉となっている。このようなことを考えると 1 年 に1度，砂棘の販売をして得られる収入よりも，毎月 確実に得られる月払いの賃労働収入を得る道を選択し ている。

今後は，子供にお金をかける必要がなくなれば，完 全に賃労働就労をやめ, 砂棘栽培に専念することを考 えている。

\section{V おわりに}

以上， D 村における砂棘栽培の現状を見てきた。 現段階の砂棘栽培においては，企業と連携していない 旧品種栽培と企業と連携している新品種栽培の 2 形態 が存在する。いずれの栽培も農牧林家の家計収入の大 きなプラスとなっており，生活に不可欠な燃料問題の 解決にも繋がり化石然料使用減少にも慗がることとな っている。しかし, この 2 形態の栽培において, 大き な開きがあることが明らかになった。

先ず企業と連携していない農牧林家であるが，これ らの農牧林家の砂棘栽培は生産物の利用のみに留ま り, 従来からある旧品種の砂棘林を利用しているため, その分布は分散しており，1站当りの収穫量は様々で あり計算できず，採取作業が困難であることなどの問 題点が存在する。また砂棘林の育成・管理はほとんど 行っておらず, 砂棘についての成長特性, 病虫害防止 などの基本知識が久如しており，剪定などの基本技術 がほとんど知られていない。従って，今後において， 長期にわたり育成・管理作業を実施せず，採取林業的 な砂棘林の取り扱いが継続していけば，気候面での乾 燥などの影響の下で砂棘林の枯死問題などの発生が予 想される。またそれらの砂棘林が枯死し存在しなくな った場合には, その栽培を行っている農牧林家の経営 状況は更に厳しくなるであろう。

次に, 企業と連携している農牧林家に招いては, 企 業から新品種が提供され, 請負った荒廃地は場所的に まとまっており，植林，刈取り，剪定，収集などにお ける一連の作業がしやすく,また企業との間において， お互いに権利と義務を尊守した上で経営を行っている ため安定した収入が確保されている。しかし企業との より緊密な連携関係の構築に至るまでには，その前提 として企業との信頼関係を構築することが必要であ り，それと同時により一層の展開のための資本の蓄積 が必要である。

以上のように，栽培方式の違いによって企業と連携 している農牧林家としていない農牧林家の間には，収 入の格差が生じている。

今後は，農牧林家間に扔ける収入の格差を無くして いくために，また従来植林していた砂棘林及び新たに

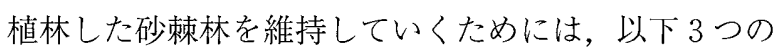
対策が考えられる。1 つは, テレビ・ラジオの放送, 新聞, 広報などの各種媒体を通じて, 企業と連携する 砂棘林経営の長所, 現在採用している政策及び関連規 定を明確にし，企業参入の重要性をアピールしなけれ ばならない。そして, 企業を紐带とし, 国家と農牧林 家を結びつけ，この3つの力を融合させることが必要 であろう。次に農林畜産業に参入する企業に対して, 
国家による資金の優先的貸付，所得税減免などの税の 優遇政策の実施だけではなく，経営の初期段階にある 農牧林家に対しても補助金の交付を行うことより砂棘 植林を拡大していくことが必要であろう。農牧林家に は林木の生産過程において，成林し収穫可能な時点に 至るまでの砂棘林育成段階においても補助金により収 入が得られ，成林するまでの経営が保証されるような 枠組みが整備されれば，農牧林家のさらなる造林への 意欲を刺激し高めることができるだろう。最後に村全 体でさらなる増収を実現させるためには，生産性を向 上させる集約的経営の確立が必要となるであろう。こ のことは，D村のみならず中国国内で経済が立ち遅 れている地域に扮いて重要な課題となるであろう。

\section{注}

* 1 「非公有制林業」(Non-public Forestry) は, 中央·地方政府による林業に対する用語であって， 日本語的に表現すれば「非公営林業」となる。

*2「三農問題」とは, 農業の低収益性, 農村の疲 弊, 農家の所得低迷と都市の住民との所得格差拡 大を指す。

* 3 筆頭 (龍頭) 企業は中国語で龍頭（先進の意） 企業という。中国の「三農問題」の解決に拉いて, 筆頭企業は農林業の産業化を図る上で戦略的で重 要な手段だと中国政府に指摘されている。一般の 企業との違いは，自身の発展を図るとともに農家 と連携し，農林業の近代化や農家所得の向上を図 ることにまで目配りしていることである。

*4「県」日本の郡の規模に相当する。内蒙古自治 区では「県」と同じ行政単位として，「旗」ある いは「蘇木」とも呼ばれている。

* 51 嘼 (ムー) は 1 ha の15分の $1 （ \fallingdotseq 0.0667 \mathrm{ha})$ である。

*6 プロゲステロンは女性ホルモンのひとつで「黄 体ホルモン」とも呼ばれる。女性の更年期障害に よるうつやイライラ，不眠，倦怠感を抑制する働 きがある。

* 7 ここでの砂棘林の分割とは，農牧林家が政府な どと契約し，一時的に経営に利用することを指し ている。

* 8 1 元う15円（2006年のレート）である。

* $91,300 \mathrm{~kg}$ の砂棘の葉は石炭（ここでは石炭は塊 炭・粉炭の混合物を指す） $1,000 \mathrm{~kg} の$ 熱量に相当 する。 4 ～ 5 年生の砂棘林 1 畧当りからは年間 $400 \mathrm{~kg}$ の落ち葉が生産される。ちなみに調査地に おける 1 農牧林家の年間における石炭の消費量は 大凡 $4,000 \mathrm{~kg}$ である。
*10 天然資源の保護区とは天然林などの自然資源の 保育，維持，拡大などのプロジェクトの実施地域 である。この地域には，長江上流，黄河上・中流 地域，東北地区，内蒙古など重点国有林業区の17 省・自治区・直轄市の734県が含まれる。2000年 から2010年までに次の 3 つの目標を実現する。1） 現有の森林資源を確実に保護すること。2）森林 資源の育成を加速すること。3）営林企業の余㮃 人員の再配置を適切に解決することである。

*11 中国内蒙古自治区地域では過放牧による砂漠化 が進み，緑化などによる砂漠化防止や自然環境の 再生のみならず，生產活動を維持していくための 適正な土地管理手法として「閉山育林」政策を採 用している。そのため 4 月から 9 月の間において， 林木の自力復旧を図るため放牧は禁じられてい る。

\section{引用文献}

（1） $\mathrm{D}$ 企業の2002年の内部資料.

(2) 大紅城郷の2004年の統計資料.

（3）倪国良（2002）経済全球化与中国農業的変革. 蘭 州大学学報 $2: 129 \sim 134$.

（4）平野悠一郎（2004）中華人民共和国における森林 関連の基本法の特徵。林業経済研究 50 (1)：53 64.

（5）何恒遠（2005）破解「三農」：一個西部貧困県的 崛起之路一関与和林格爾農牧業産業化的調査報 告. 経済研究参考 18 (1) : 40 48.

（6）景宏偉 · 張耀 · 丁寧 · 宋増峰 (2006) 砂棘在生態 環境治理中的応用及其前景. 陝西省林業経済 14 (1) $: 35 \sim 38$.

(7) 国家九五星火計画綱要 http://www.chinatech.com.cn/aspx/kejiziliao/kejijihua /xinghuo/xinghuo08.htm.

(8) 蘭登明（2005）大果砂棘及其開発前景. 銭学森与 内蒙古検討会論文集. 215 - 223，310pp，内蒙古 自治区出版社，内蒙古自治区.

（9）李根前 - 唐徳瑞 - 趙一慶（2000）中国砂棘属植物 資源与開発利用。砂棘 $\mathbf{1 3}(2): 22 \sim 26$.

(10) 朱俊鳳 (2004) 中国砂産業.481pp，中国林業出 版社，北京。

(11) 周立群 (2004）農業産業化経棠中経済組織的演変 与創新. 南開大学政治経済研究中心.

(12) 唐小麗 (2002) 中国南方山区開発成功模式研究一 竹業龍頭企業与社区農戸的合作関係．北京林業大 学.

(13) 徳岡正三 (2003) 砂漠化と戦う植物たち. 171, 241 
$\mathrm{pp}$ ，研成社，東京.

(14) 中共中央国務院促進農民増収的“意見”

http://news.sohu.com/2004/02/08/50/news21898509 0. shtml

(15) 和林格爾県人民政府 (2004) 和林格爾県的林業発 展歴程． 36 37，73pp，和林格爾人民出版社，和
林格爾県.

(16) 吉川賢 (1998) 砂漠化防止への挑戦. 30～31, 215 pp, 中央公論社，東京.

(2007年 2 月 1 日受付) (2007年 4 月 24 日受理) 